\title{
O LIVRO DE CESÁRIO VERDE: LEITURAS E COMPARAÇÕES
}

Roberto Daud

Universidade Federal de Uberlândia

\section{1. "Um poeta do nosso tempo"1}

A obra de José Joaquim Cesário Verde (1855-1886) é relativamente pequena: toda sua produção lírica compreende um único livro com quarenta e dois poemas. Alguns deles saíram em jornais e revistas da época, outros, porém, permaneceram inéditos até 1887, ano em que seu amigo Silva Pinto organiza e publica postumamente $O$ livro de Cesário Verde.

Os poemas de estréia de Cesário Verde podem ser considerados uma crítica mordaz e bem-humorada ao sentimentalismo ultra-romântico. Nessa fase mais juvenil, ele tenta a via do realismo literário, trilhada em Portugal pela Geração de 70. ${ }^{2}$ Seguindo “as pisadas de João Penha” (COELHO, 1972, p.194). Cesário Verde cultiva a surpresa do final contrastante e irreverente, acentuando assim o significado paródico do poema. ${ }^{3}$ Levados por certa iconoclastia, os primeiros poemas queriam mostrar que a poesia sentimental não passava de retórica vazia.

\footnotetext{
COELHO, 1972, p.198.

2 Apesar de Cesário Verde não ter convivido com o grupo de Antero de Quental e Eça de Queirós, ele parece "perfeitamente sintonizado com a filosofia social da Geração 70, de quem é, afinal, o grande poeta" (LOURENÇO, 1991, p.996)

3 "Este tom de zombaria, de humor cáustico e quase sempre inesperado encontra-se também nos versos de João Penha e Gomes Leal, e é retomado por Cesário, às vezes com graça incomparável" (BERARDINELLI, 1988, v.2. p.92-120).
} 
Essas irônicas referências à literatura ultra-romântica encontram-se também na figura da "grande dama fatal", tal como aparece em Esplêndida, Deslumbramentos e Humilhações. Todavia, a fleumática senhora e seu alucinado voyeur não comportam apenas uma crítica ao sentimentalismo, também é possível reconhecê-los como protagonistas do "próprio drama da vida pública” (SENNETT, 1988, p.229) vivido no século passado. Na emblemática mulher fatal percebe-se uma crítica à sociedade da época, à luz do ideário da Geração de 70, que defendia a liberdade e a autonomia do indivíduo: “o escritor pretendia-se cidadão e não vassalo” (FERREIRA, 1979, p. 194). O republicano Cesário Verde ironiza esse perfil feminino, extemporâneo e dissonante com as relações do mundo moderno.

Nos poemas Manhãs Brumosas e De verão, o retrato feminino torna-se mais denso e complexo. Embora apareça num cenário rural, a mulher apresenta modos caracteristicamente urbanos. Em Manhãs Brumosas, a jovem irlandesa, exibindo "os grossos tornozelos", e a prima loira, em De Verão, realizando "um pulo de ginasta” sobre um formigueiro, são figuras representativas do lento processo de liberação da mulher que se inicia em meados de 1800 até tornar-se uma "revolta em grande escala" (SENNETT, 1988, p.229) nas primeiras décadas do século XX. O desejo de libertar o corpo e expressar as próprias idéias pode ser percebido na inquieta irlandesa que, com atitudes de comando, desafia o "poeta inglês", e na sensível moça loira que ousa questionar os valores do primo proprietário. No esforço de alcançar maior liberdade de expressão, as duas jovens acabam retratando a opressiva condição feminina da época.

\section{2. "Um pintor nascido poeta" 4}

Vários estudiosos aproximam a poesia de Cesário Verde da pintura moderna. De fato, como os impressionistas franceses, o poeta colhe flagrantes no dia-a-dia familiar, nos alegres fins-de-semana, numa rua em obras, numa loja iluminada e, até mesmo, no submundo urbano. ${ }^{5} \mathrm{O}$ valor estético

MOURÃO-FERREIRA, 1967, p.97-134.

Cesário Verde "abriu à poesia as portas da vida, e nela entraram os ruídos, os cheiros e a linguagem das ruas". (COELHO, 1972, p.194). 
das imagens de Cesário Verde pode ser definido pela recusa ao grandioso e monumental e pela valorização do simples e do prosaico. Seu lirismo pictórico provém de uma acurada atenção visual à vida diária e comum. Em $D e$ tarde, o poeta percebe no domingueiro "pic-nic de burguesas" uma cena que "em todo caso dava uma aquarela". As cores vibrantes do "ramalhete rubro de papoulas", a delicadeza de "um granzoal azul de grão de bico" e as formas redondas dos "dois seios como duas rolas" são imagens que mais parecem uma celebração sensorial que um simples almoço campestre.

Esse pequeno poema de Cesário Verde lembra, em alguns aspectos, Le déjeuner sur l'herbe (1863) de Manet. Como a famosa tela, De tarde pode ser interpretado como uma pastoral moderna, criada "sem histórias, nem grandezas”. O poeta português, num trabalho semelhante ao do pintor francês, procura resgatar a poesia do bucolismo, instalando sem ninfas nem pastores o quadro pastoral no mundo cotidiano. No seu "almoço na relva", Cesário Verde procura reencontrar o silêncio de uma natureza sem retórica. Poeticamente, o cenário campestre sobrevive porque se torna menos “pastoral” e mais real. Dessa maneira, o mito da arcádia renasce na medida em que é retratado sem "imposturas tolas".

Cesário Verde revela uma sensibilidade pictórica característica de meados do século passado: importava mais a impressão do objeto do que a infindável enumeração de detalhes. À semelhança de uma tela pintada en plein-air, em Num bairro moderno e Cristalizações, o poeta consegue captar a luz dos raios solares refletidos nas porcelanas de um almoço matinal, num profuso cesto de verduras, nas gotas que caem de um regador, nas poças de água de uma rua em obras e nas cores das árvores mergulhadas na neblina.

Num bairro moderno também mostra um Cesário Verde mais próximo do lirismo oitocentista que, desde Baudelaire, está “associado à representação do feio, do sórdido e dos aspectos mais horrendos da vida” (AUERBACH, 1973, p. 192- 221). Nas ruas de um bairro lisboeta, debaixo do forte sol de verão, um debilitado empregado do comércio cruza com uma franzina verdureira. Ambos são figuras representativas dessa tendência da lírica do século XIX que procura intensificar a impressão de realismo.

Cesário Verde descreve o profuso cesto de verduras da rapariga com os traços “alegres e benfazejos” (BAKTHIN, 1987, p. 17) da estética do grotesco, valorizando dessa maneira a função nutritiva das frutas e legumes. 
"E recebi, naquela despedida, / as forças, a alegria, a plenitude, / Que brotam dum excesso de virtude/ Ou duma digestão desconhecida”. É visível a discrepância entre as linhas simétricas e acabadas da casa burguesa e as formas incompletas e "em estado de prenhez e parto" (Idem, p. 23) do cesto de verduras: "e, entre as hortaliças, túmido, fragrante,/ Como d'alguém que tudo aquilo jante/ Surge um melão, que me lembrou um ventre”. As contraditórias relações do mundo urbano com uma natureza nutriente ficam evidenciadas pelo forte contraste entre o exuberante cesto da rapariga e a fria arquitetura das mansões, as janelas fechadas com persianas, as paredes com papel pintado e as ruas macadamizadas do bairro moderno.

Depois de Num bairro Moderno, aparece Cristalizações, que se inicia com uma sensível pintura da luz de inverno refletida nas poças de água de uma rua em obras. O poema retrata também o árduo trabalho de pavimentação realizado pelos calceteiros. O conjunto de imagens compõe uma espécie de painel articulado "em termos conscientemente dialéticos" (SACRAMENTO, 1959). Ao descrever os trabalhadores braçais como "homens de carga”, Cesário Verde deixa perceber sua identificação com a "filosofia social da Geração de 70, pelo protesto-via Hugo contra as misérias anônimas e dolorosas” (LOURENÇO, 1991, p. 975). Contudo, mais que a admiração pelo romantismo social hugoano, a detida e invulgar sensibilidade visual define melhor o poeta Cesário Verde.

Segundo Oscar Lopes, a tela Les casseurs de pierre de Courbet serviu de modelo para os calceteiros de Cristalizações. ${ }^{6}$ De fato, além de ser comum ao poeta e ao pintor o tema do trabalho do homem com as pedras, é possível perceber também uma semelhança de tratamento entre o aspecto petrificado conferido por Courbet à figura do britador, e os traços da imagética animal atribuídos aos calceteiros por Cesário Verde. Contudo, o quadro e o poema apresentam outros traços de proximidade: tanto Courbet como Cesário Verde rejeitam a idealização romântica e tentam a via do realismo. A figuração zoomórfica dos calceteiros em Cristalizações e a petrificação do britador

6 "Outro exemplo de exactidão descritiva evidencia-se nos calceteiros de Cristalizações. O assunto foi provavelmente inspirado no célebre quadro de Courbet que Eça apontou na sua conferência-manifesto de 1871 como modelo de realismo" (LOPES, 1967, p. 257-265). 
em Les casseurs de pierre foram motivadas pelo idêntico propósito de alcançar uma representação mais verdadeira do trabalho braçal.

Courbet, assim como Cesário Verde, quis apresentar não apenas um homem, mas a própria imagem do trabalho reificador, transformando até mesmo a maneira de pintar num elemento significativo de composição da tela. Tanto o pintor como o poeta rompem com o realismo linear para chegar a uma forma de representação mais elaborada. Aprofundando o processo mimético, eles criam imagens "sem contornos meramente descritivos" (ARGAN, 1992, p. 70) que, de certa forma, antecipam a poesia e a pintura modernas. Pode-se dizer que, assim como o pintor francês, o poeta português ultrapassa "o realismo meramente estético ao procurar fazer um retrato verdadeiro da sociedade contemporânea” (AUERBACH, s.d., p.446).

\section{O mundo utópico}

Os primeiros tempos da iluminação urbana transformaram as ruas num espetáculo fascinante, sobretudo para nosso poeta que parecia ter "os olhos de artista plástico" (COELHO, 1961, p.181). Contudo, também é possível dizer que a sensibilidade visual de Cesário Verde tem relação com o advento da fotografia. Seu incansável trânsito pela cidade parece motivado pela vontade de descobrir, sob a luz dos lampiões, cenas rápidas e incidentais, instantâneos, flagrantes e ângulos inesperados da vida urbana. Talvez seja possível dizer que $O$ sentimento dum ocidental, "poema-mito do universo de Cesário Verde” (LOURENÇO, 1991., p. 977), tenha reflexos dessa mudança do modo de olhar, provocado por duas conquistas técnicas da época: a fotografia e a iluminação urbana.

Na última parte de $O$ sentimento dum ocidental, surgem imagens visionárias que contrastam com o fotográfico recorte da paisagem urbana. Andando pelas ruas escuras, depois de apagados os lampiões, o poeta sonha com o futuro, antevendo as famílias e as casas de um novo tempo: "esqueço-me a prever castíssimas esposas, / Que aninhem em mansões de vidro transparente”. Talvez o sonho de habitar as "translúcidas e frágeis" mansões tenha raízes no desejo de evadir-se daquela "massa irregular de prédios sepulcrais". "Triste cidade": a arquitetura utópica torna-se, pelo avesso, a representação mais 
verdadeira da sombria capital portuguesa. "Eu quero as vossas mães e irmãs estremecidas / Numas habitações translúcidas e frágeis". ${ }^{7}$

Em $O$ sentimento dum ocidental, Cesário Verde realiza um trabalho quase fotográfico sobre o mundo lisboeta. No entanto, no final do poema, a "objetiva" do poeta parece funcionar ao contrário: a "fotografia" torna-se mais nítida se vista pelo seu negativo. As futuras "mansões de vidro transparente" visionadas pelo poeta acentuam o aspecto lúgubre e sombrio da capital. O retrato da cidade não é meramente fotográfico: ele nasce da "correspondência exata entre a visão interna e externa” (MONTEIRO, 1977, p. 29) do poeta. Portanto, "adjetivar a poesia de Cesário Verde de realista é uma atitude que tem tanto de simplista como de insatisfatória” (COIÁS, 1955, p.733). O poeta supera a objetividade unívoca de sua época para alcançar um âmbito de representação amplo e aberto e, por isso mesmo, mais realista. As luzes do tempo vindouro são as que de fato clareiam a cidade "às escuras", tornando-se a imagem mais reveladora de "uma Lisboa que só ele podia ter visto, e só ele podia trazer até nós para então a reconhecermos" (MONTEIRO, 1997, p. 30).

No seu extenso poema Nós, Cesário Verde enaltece o trabalho agrícola. Parte do poema é constituído pela descrição de tipos de plantas e de plantio, de áreas de cultivo, de pragas, de utensílios, de qualidade de frutas, de termos do comércio e exportação de frutas. $\mathrm{O}$ poeta tenta resgatar a sensação original das coisas, recorrendo a nomes específicos, encontrados, na maior parte, no léxico do mundo rural. Os termos do mundo agrícola entram no "terreno sagrado" do poético, dando a impressão de que o longo poema nasce de um duplo esforço: aproximar a linguagem lírica do mundo prático e, ao mesmo tempo, descobrir a poesia das coisas "probas, úteis, dignas, boas".

7 Há algumas semelhanças entre as translúcidas habitações de Cesário Verde e os falanstérios de Charles Fourier (1772-1837). É preciso observar que, de forma coincidente ou não, o vidro é o componente arquitetônico fundamental das mansões visionadas por Cesário Verde como também da habitação comunitária idealizada pelo pensador francês. Em seu ensaio Fourier ou as passagens, Walter Benjamin aponta para a relação entre os falanstérios e as galerias parisienses, nas quais "se amplia o campo de aplicação arquitetônica do vidro" (BENJAMIN, 1985, p.32). 
Embora o trabalho com a terra possa ser considerado o tema central do poema, a morte também é um motivo poético importante. Cabral Martins esclarece que "há em Nós um biografema oculto talvez mais presente do que os outros que são explícitos: a doença mortal de que Cesário Verde se encontra já atingido a partir de 1884” (MARTINS, 1988, p. 95). Sentindo-se ameaçado pela "terrível aniquilação" que vitimava a população da capital, o poeta refugia-se na idéia de transformar a propriedade agrícola numa inexpugnável barreira contra as doenças da época. "Somos fortes! As nossas energias/ Tudo vencem e domam muito bem!”. Ele procura se convencer que "uma aldeia daqui é mais feliz", comparada com a "Londres sombria" e com "as febris oficinas estridentes” da Inglaterra industrial. No entanto, a prematura morte da irmã, ocorrida nesse "mundo solar e inaugural" (MENDES, 1979, p.11-70), causa um forte abalo no pragmatismo otimista do poeta. Depois, frustrando suas esperanças de continuar "rijo e resistente" no saudável mundo campestre, ele não consegue impedir que a morte atravesse a fortaleza agrícola de forma ainda mais avassaladora.

Sabe-se que, no século XIX, surgiram diversos projetos de comunidades agrícolas, gerados, na sua maior parte, pela crítica à triunfante sociedade industrial. Contudo, pode-se perceber que o sonho de Cesário Verde, como negação das "febris oficinas estridentes", "fábricas a vapor" e "tristes fiações”, não é motivado pela vontade de transformação histórica. Também não apresenta os traços de ruptura com a ordem social que fundamentalmente caracterizam as mais conhecidas propostas comunitárias da época. A saudável vida no campo, onde “o santo sol” torna tudo mais "espontâneo, alegre, tosco, facílimo, evidente, salutar” é enaltecida sobretudo porque o mundo rural parece ser o melhor abrigo para o clã patriarcal. Essa situação de refugiado chega a um dramático impasse: depois da morte da irmã, o poeta ainda tenta legitimar um implacável processo de seleção sem perceber que, contraditoriamente, está justificando o seu próprio desaparecimento. "Pobre da minha geração exangue de ricos!".

Segundo Alberto Ferreira, o utopismo da Geração de 70, nas últimas décadas do século, “perdera a sua vigência prática” (ALBERTO, 1979, p. 192), deixando perceber que "a revolução estava irremediavelmente adiada” (Idem, p. 193). De certa forma, o pensamento utópico oitocentista, perceptível na produção literária de Antero de Quental, ilumina também a obra de Cesário 
Verde. Contudo, "os seus sonhos, as suas aspirações não perdem nunca o contato do senso comum a que reagem às vezes corpo a corpo" (LOPES, 1967, p.264). Embora o grupo de Eça de Queirós tenha se tornado para o público do século passado "o expoente de uma revolta e de um revolucionarismo bem mais ostentatórios que aqueles que se podem perceber na obra de Cesário Verde" (LOURENÇO, 1991, p.975), o poeta de $O$ sentimento dum ocidental conseguiu como ninguém elaborar "essa imagem feroz e clínica do tempo" (Idem, p.981), que é o traço insuperável de sua breve obra.

\section{BIBLIOGRAFIA}

ALBERTO, Ferreira. Perspectiva do romantismo português. 2.ed. Lisboa: Moraes, 1979. ARGAN, Giulio Carlo. Arte Moderna. São Paulo: Companhia das Letras, 1992, p. 70.

AUERBACH, Erich. "Les fleurs du mal di Baudelaire e il sublime”.Da Montaigne a Proust. Milano, Garzanti, 1973.

. Mimesis. São Paulo: Perspectiva, s.d..

BAKTHIN, Mikhail. A cultura popular na Idade Média e no Renascimento: o contexto de François Rabelais. São Paulo: Hucitec, 1987.

BENJAMIN, Walter. Paris, capital do século XIX In: Walter Benjamin. São Paulo: Ática, 1985. BERARDINELLI, Cleonice. “Cesário Verde entre Fradique e Sá-Carneiro”. In: Boletim do Sesesp. Rio de Janeiro, UFRJ,1988.

COELHO, Jacinto do Prado. "Um clássico da modernidade: Cesário Verde”. Problemática da História Literária. 2 ed. Lisboa: Ática, 1961.

COELHO, Prado Jacinto do. “Cesário Verde escritor”. Problemática da História Literária. Lisboa: Ática, 1972.

COIÁS, Elisa Lopes. “Cesário Verde, poeta realista?”. Cadernos de Literatura, n 16, Coimbra, dezembro de 1955.

FERREIRA, Alberto. Perspectiva do romantismo português. 2.ed. Lisboa: Moraes, 1979.

LOPES, Oscar. Cesário, ou do naturalismo ao modernismo. Vértice. Coimbra, v. XXVII, n. 284, maio de 1967.

LOURENÇO, Eduardo. “Os dois Cesários”. Estudos portugueses. Lisboa: Difel, 1991.

MARTINS, Cabral. Cesário Verde, ou a transformação do mundo. Lisboa: Comunicação, 1988.

MENDES, Margarida Vieira. Apresentação crítica. In: Poesias de Cesário Verde. Lisboa: Comunicação, 1979.

MONTEIRO, Adolfo Casais, A poesia portuguesa contemporânea. Lisboa: Sá da Costa, 1977. 
MOURÃO-FERREIRA, David. “Notas sobre Cesário Verde”. In: Hospital das Letras. Lisboa: Moraes, 1967.

SACRAMENTO, Mário. "Lírica e dialética em Cesário Verde”. Vértice. Coimbra, separata dos n.163-166, abril-jul. 1959.

SENNETT, Richard. O declínio do homem público. São Paulo: Companhia das Letras, 1988. 